\title{
ハンセン病の後遺症による難治性下肢神経障害性 疼痛に対して五苓散が著効した一症例
}

\author{
田島 康介 ${ }^{\mathrm{a}}$ 吉田 祐文 ${ }^{\mathrm{a}}$ 松村 崇史 ${ }^{\mathrm{b}}$
}

a 大田原赤十字病院整形外科, 栃木, $=324-8686$ 大田原市住吉町 2-7-3

$\mathrm{b}$ 松村外科整形外科医院，栃木， = 320-0026 宇都宮市馬場通り1-1-6

\section{Effect of Goreisan in Refractory Neuralgia after Hansen's Disease}

\author{
Kosuke TAJIMA $^{\mathrm{a}}$ Hirobumi YOSHIDA $^{\mathrm{a}}$ Takashi MATSUMURA $^{\mathrm{b}}$
}

a Department of Orthopaedic Surgery, Otawara Red Cross Hospital, 2-7-3 Sumiyoshi-cho, Otawara, Tochigi 324-8686, Japan

b Matsumura Surgery and Orthopaedic Clinic, 1-1-6 Babadori, Utsunomiya, Tochigi 320-0026, Japan

\begin{abstract}
Hansen's disease (HD) is a chronic infectious disease caused by the Mycobacterium leprae, which parasitizes skin macrophages and Schwann cells of peripheral nerves. Left untreated, leprosy can be progressive, causing permanent damage to the skin, nerves, limbs and eyes due to sensory disturbance and neuritis. Many HD patients suffer from refractory neuralgia for which neither painkillers nor other western medicine are usually effective. Here, we will report the case of an 85 year-old male, whose refractory neuralgia remarkably improved with goreisan. The mechanisms by which goreisan was effective may be as follows : (1) neuralgia pathology is an interstitial edema of peripheral nerves, and can explain as a local Sui-doku, a specific Sho for goreisan; (2) peripheral nerve ischemia, caused by scar formation from chronic inflammation, leads to dysfunction of $\mathrm{Na}^{+} / \mathrm{K}^{+}$ATPase, and extracellular potassium concentration increases. This environmental change leads a neural hypersensitivity, and goreisan is known to decrease extracellular potassium concentrations. This case suggests goreisan might be worth considering for use in refractory neuralgia, not only in HD patients, but also in other neuropathies.
\end{abstract}

Key words : Hansen's disease, goreisan, neuralgia

\begin{abstract}
要旨
八ンセン病の後遺症による難治性下肢神経障害性疼痛に対し, 漢方薬である五苓散（エキス剂）が著効した症例 を経験したので報告する。【症例】85歳，男性。ハンセン病による右下肢神経痛に対し NSAIDs やその他の西洋薬 が無効なため, ペンタゾシンを約 5 年もの間，連日投与されていた。漢方医学的には全身には水毒を認めなかった が, 考察で論ずる理由から五苓散を投与したところ急速に症状の寛解が得られた。考察】末梢神経では慢性炎症に より浮腫と線維化が進行するとされる。（1）末梢神経の線維化により局所の血流障害がおこると Na/K-ATPase ポンプが抑制されるため, 細胞外 K濃度が増加して神経の易興奮性を生じるが, 五苓散には細胞外Kの調節作用が 存在することが知られている。また，（2）本症例は漢方医学的には水毒を認めなかったが, 神経の腫大化すなわち 神経浮腫は局所の水毒と考えられる。この二つのメカニズムにより，五苓散が奏効したものと考えられた。 キーワード : ハンセン病, 五苓散, 神経痛
\end{abstract}

\section{はじめに}

ハンセン病は抗酸菌の一種であるらい菌（Mycobacterium leprae）の皮膚のマクロファージ内寄生お よび末梢神経細胞内寄生によって引き起こされる感 染症である。現在は治療法が確立されたために重度 な後遺症が残存するまで症状が進行することはない が，依然本邦においても後遺症に苦しむ患者は少な くない。今回, 西洋医学的に改善の得られなかった
難治性の下肢神経障害性疼痛に対して, 漢方薬であ る五苓散が著効した症例を経験したので報告する。 【症例】85歳, 男性。

13歳時に右腕の知覚障害にて発症し, 16歳時に八 ンセン病療養施設に入所, 30歳時に眼病変により失 明をしている。下肢痛に関しては50歳前後より発症 し，非ステロイド性消炎鎮痛剤（NSAIDs）やその ほか内服薬が無効なハンセン病による右下肢神経痛 
のため, 過去にもペンタゾシン (ソセゴン $\left.{ }^{\circledR}\right)$ 注射 液を断続的に投与されてきた。平成13年（75歳時） よりペンタン゙シンの使用頻度が増し, 平成15年以後 6 年もの間, 毎日 1 回のペンタゾシン投与を連続し て受けてきた。右膝窩に弾性硬の膨隆をみとめ（図 1 ), 圧痛や Tinnel 徵候をみとめたため腫大した膝 窩神経と考えられたため, 平成18年からは同部に週 1 回の右膝窩神経ブロック（リドカインおよびステ ロイド）を併用するようになった。

平成21年 5 月，これ以上の西洋医学的な対応では 患者の症状を改善できないと考え, 筆者は漢方医学 的なアプローチを検討した。労作時の息切れ，脱毛， 皮膚の乾燥や荒れ，爪の肥厚を認め，また腹診上， 軽度の胸脇苦満, 小腹不仁, 軽度の臍上悸をみとめ た。一方, 手指・四肢のむくみ, 口渇, 下痢, 心窩 部振水音などは認めなかった。舌は非薄化し, 舌根 から舌中にかけて褐苔を伴う皺裂を認めた。また舌 下静脈には明らかな怒張を認めなかった。以上のよ うに漢方医学的に明らかな水毒を認めず，気血両虚 として対応すべきと考えられたが，考察で後述する 理由から五苓散（クラシエ， $6 \mathrm{~g} /$ 日）を投与した。 すると, 投与 3 日目から症状の軽減を自覚し, 2 週 目で神経痛が半減， 3 週目には以前の $1 / 10$ 程度に まで症状が改善し, ペンタゾシンが不要となった。 さらに 7 週目からは膝窩神経ブロックも不要となり, 以後五苓散のみの投与で症状は宽解した。

なお，採血上経過中の血中 $\mathrm{K}$ 值はいずれも正常 範囲内であったが，五苓散投与前は $4.6-5.0 \mathrm{mEq} /$ $\mathrm{L}$ であった $\mathrm{K}$ 值は五苓散投与後に $4.2-4.3 \mathrm{mEq} / \mathrm{L}$ に若干低下する傾向を示した。

\section{考察}

ハンセン病の病原菌であるらい菌は末梢神経の構 成要素であるシュワン細胞に寄生するので，ハンセ ン病は本質的には末梢神経の感染症である。ハンセ ン病の末梢神経障害の様相は, らい菌の増殖に適す る環境条件と, 宿主側の免疫応答の条件により決定 される。これに痛覚脱失による外傷や火傷による組 織欠落, 肥厚した神経に生じる絞扼性ニューロパ チーなどによってハンセン病の臨床像が形成される。

ハンセン病による神経痛は，急性の神経炎を繰り 返し遷延化することで徐々に神経の腫大や線維化が 進行し, 突然の電撃痛発作を繰り返し来たすように なる ${ }^{1)}$ 。病理学的には神経内膜の浮腫と神経線維の

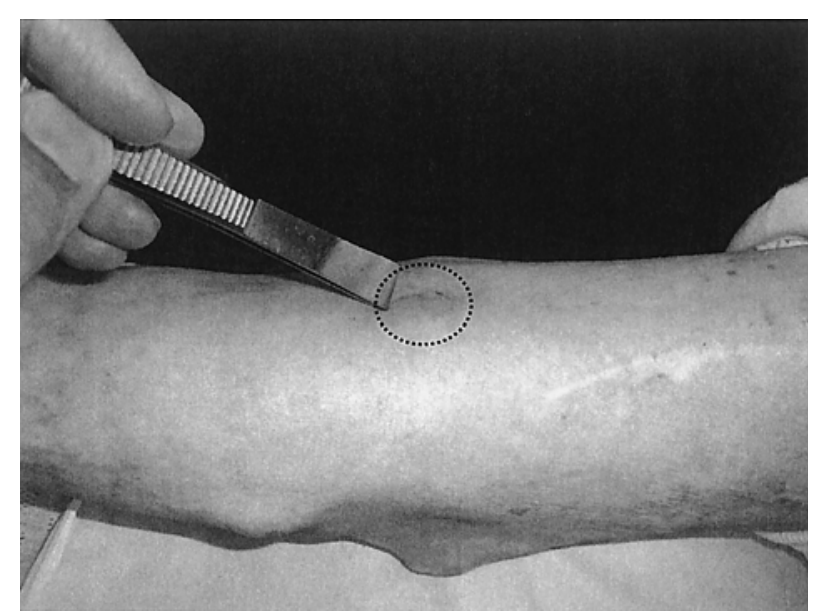

図 1

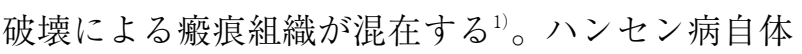
はジアフェニルスルホン，クロファジミン，リファ ンピシンなどによる多剤併用療法で治癒可能な疾患 ではあるが，一度完成してしまった神経の器質的変 化に起因する種々の症状に対しては NSAIDs やビタ ミン $\mathrm{B} 12$ 製剤などの効果は低く, 抗うつ薬，抗㾏攣 薬，麻薬系鎮痛剂を組み合わせて使用することが多 いが，症状のコントロールには難渋する。

Bostock（1991）は末梢神経の線維化により局所 の血流障害が抢こると酸素の供給が低下し, TCA サイクルに扔けるアデノシン三リン酸（ATP）の産 生が障害されるために, 神経細胞膜において細胞内 の $\mathrm{Na}^{+}$を排泄し細胞外の $\mathrm{K}^{+}$を取り込む $\mathrm{Na}^{+} / \mathrm{K}^{+} \mathrm{AT}-$ Pase ポンプを抑制すると報告し ${ }^{2)}$ ，そのために細胞 外の $\mathrm{K}^{+}$濃度が上昇し神経細胞が脱分極しやすい状 況となり，結果として神経が易興奮性となるために しびれが生じやすくなるものと考えられる。一方で 田島 ${ }^{3}$ は，いかなる西洋薬も無効であったが透析患 者の高 $\mathrm{K}$ 血症に対して五苓散が著効した症例を報 告し, 透析で廃絶している腎以外での細胞外 $\mathrm{K} の$ 調節作用を五苓散が有する可能性を報告し, 内藤 ${ }^{45)}$ はこれを追試し確認している。従って，五苓散によ る細胞外 $\mathrm{K}$ 濃度の低下は, 神経痛軽減のメカニズ ムの一つとして考えられる。

また，慢性炎症や血流障害に伴う神経の腫大化は 病理学的には神経内膜組織の浮腫である ${ }^{6)}$ 。本症例 は漢方医学的に全身の水毒を認めなかったが, 本症 例は膝窩部に腫大した膝窩神経を認めており，この 神経の腫大化すなわち神経浮腫は局所の水毒と考え ることができるので，五苓散はよい適応となる。 
このように，ハンセン病による神経障害性疼痛を， 病理学的に観察される神経の線維化と浮腫が原因で あると考察し，神経の線維化による血流障害に起因 する易興奮性と，神経浮腫すなわち局所の水毒とを 改善する目的で五苓散を投与したところ著効した。 他の難治性の神経障害性疼痛にも五苓散が有用であ る可能性があり，わずか一例の小経験ではあるが貴 重な症例と考え報告した。

\section{引用文献}

1) 後藤正道：ハンセン病にみられる神経障害について, 大谷藤郎監修 総説現代ハンセン病医学, 第 1 版, pp 153-164，東海大出版会，神奈川，2007

2 ) Bostock H, Baker M, Reid G: Changes in excitability of human motor axons underlying post-ischemic fasciculations ; evidence for two stavle states. J Physiol441, 537557, 1991

3 ) 田島康介, 松村崇史：漢方薬による関節症の治療中に 血清カリウム值が正常化した透析患者の 1 例. 漢方と 最新治療12，367-369，2003

4 ) 内藤真礼生：五苓散エキス製剤による慢性腎不全患者 の高カリウム血症抑制効果 イオン交換樹脂に変わる カリウム抑制剂となる可能性について, 日東医誌 57 別，245，2006

5 ) 内藤真礼生：五苓散エキス製剂による慢性腎不全患者 の高カリウム血症抑制効果（続報） 血清 $\mathrm{K}$ 值に応 じた効果，日東医誌58別，262，2007

6 ) Mackinnon SE, Dellon AL: Internal neurolysis, in : Surgery of the peripheral nerve. pp131-148, Thieme, New York, 1998 